TELEMATIKA, Vol. 14, No. 01, APRIL, 2017, Pp. $33-38$

ISSN 1829-667X

\title{
ANALISIS DAMPAK FAKTOR CUSTOMER RELATIONSHIP MANAGEMENTDALAM MELIHAT TINGKAT KEPUASAN DAN LOYALITAS PADA PELANGGAN MARKETPLACE DI INDONESIA
}

\author{
Bala Putra Dewa, Djoko Budiyanto Setyohadi \\ Program Studi Magister Teknik Informatika, Program Pascasarjana,Universitas Atma Jaya \\ Yogyakarta, Yogyakarta, Indonesia \\ e-mail : balaputraaa@gmail.com, djokobdy@gmail.com
}

\begin{abstract}
The development in the globalization era is very rapid from year to year, The era of technology also follows the times. For example, online business. These businesses are in dire need of technology in building relationships with their customers. In Indonesia, PT Tokopedia Indonesia is one of the online businesses that implement Customer Relationship Management in maintaining relationships with their customers. The company has a website selling and buying online which is an example of a marketplace in Indonesia. This research is conducted by using descriptive method which begins by conducting survey or interview to find the necessary data, such as Tokopedia customer satisfaction level data on given service and data of level how often customer do transaction. The data - the data will be analyzed to see the level of customer loyalty on tokopedia website.
\end{abstract}

Keywords: Customer Relationship Management, Tokopedia, Online

\section{Abstrak}

Perkembangan era globalisasi sangat pesat dari tahun ke tahun, era teknologi pun mengikuti perkembangan zaman. Contohnya pelaku bisnis online. Pelaku bisnis ini sangat membutuhkan teknologi dalam membangun hubungan dengan para pelanggannya. Di Indonesia, PT Tokopedia Indonesia adalah salah satu pelaku bisnis onlineyang menerapkan Customer Relationship Management dalam menjaga hubungan dengan pelanggan mereka. Perusahaan tersebut memiliki website jual beli online yang merupakan contoh marketplace di Indonesia. Penelitian ini dilakukan dengan menggunakan metode deskriptif yang dimulai dengan melakukan survei atau wawancara untuk menemukan data - data yang diperlukan, seperti data tingkat kepuasan pelanggan Tokopedia terhadap pelayanan yang diberikan dan data tingkat seberapa sering pelanggan melakukan transaksi. Data - data tersebut nantinya akan dianalisis untuk melihat tingkat loyalitas pelanggan pada website tokopedia.

Kata Kunci: Customer Relationship Management, Tokopedia, Online

\section{PENDAHULUAN}

Persaingan dunia usaha semakin ketat dari tahun ke tahun, persaingan tersebut selalu dipengaruhi oleh peran teknologi didalamnya. Peran teknologi dalam mendukung proses bisnis perusahaan sangat berdampak positif bagi perusahaan, dengan adanya peran teknologi dalam proses bisnis tersebut, perusahaan dapat menghemat waktu dalam memberikan pelayanan kepada pelanggan. Oleh karena itu, kepuasan pelanggan sangat penting bagi pelaku dunia usaha, sebab dengan meningkatnya kepuasan pelanggan terhadap pelayanan yang diberikan akan berdampak kepada loyalitas pelanggan sehingga pelanggan dapat memberikan rekomendasi kepada orang lain. Kepuasan pelanggan sering dijadikan tolak ukur keberhasilan pelaku usaha dalam memberikan sebuah pelayanan.

Kepuasan pelanggan terhadap pelayanan yang diberikan akan berbanding lurus dengan tingkat loyalitas pelanggan. Loyalitas pelanggan akan menjamin pelaku usaha untuk tetap memberikan pelayanan yang terbaik agar pengunjung selalu bertambah dari waktu ke waktu.

Selain adanya peran teknologi dalam proses bisnis perusahaan, terdapat peran yang cukup penting, peran tersebut adalah strategi perusahaan dalam menjaga hubungan dengan 
para pelanggannya, yaitu Customer Relationship Management. Strategi tersebut banyak digunakan oleh pelaku dunia usaha. Salah satunya di Indonesia, strategi Customer Relationship Management cukup popular digunakan. Salah satu pelaku usaha yang menggunakan strategi tersebut adalah PT Tokopedia Indonesia.

PT Tokopedia Indonesia adalah salah satu marketplace yang ada di Indonesia yang menerapakan strategi Customer Relationship Management dalam menjaga hubungan baik dengan para pelanggannya. PT Tokopedia Indonesia mempunyai sebuah website jual beli yang cukup digemari oleh masyakarakat Indonesia. Selain itu, PT Tokopedia memberikan kesempatan bagi para pelaku bisnis lainnya untuk melebarkan jangkauan bisnis nya ke seluruh Indonesia dengan adanya website jual beli online mereka.

\section{TINJAUAN PUSTAKA}

\subsection{Customer Relationship Management}

Customer Relationship Management (CRM) merupakan suatu proses menggali informasi yang dibutuhkan secara detail dan keseluruhan mengenai kebiasaan - kebiasaan serta kebutuhan pelanggan untuk memaksimalkan loyalitas pelanggan. (Kotler dan Keller, 2009), sedangkan menurut Buttle (2007) mendefinisikan CRM sebagai strategi utama bisnis didalam sebuah perusahaan mengenai fungsi - fungsi internal untuk menciptakan dan mewujudkan nilai tambah bagi pelanggan. Kemudian Troot (2002) mempunyai definisi berbeda mengenai CRM. Troot (2002) mendefinisikan bahwa CRM merupakan sebuah kolaborasi antar pelanggan dan perusahaan yang mampu menciptakan suasana atau keadaan yang tidak merugikan orang lain.

Penerapan CRM didalam sebuah perusahaan dapat berperan penting dalam strategi untuk meningkatkan penghasilan perusahaan. Dengan adanya penerapan CRM akan memudahkan pelanggan untuk memenuhi kebutuhan, ketika kebutuhan berhasil dipenuhi, maka pelanggan akan loyal kepada perusahaan karena mendapatkan kepuasan terhadap pelayanan yang diberikan.

Didalam CRM, terdapat beberapa fase - fase dan kegiatan utamanya. Fase - fase tersebut antara lain Accquitition, fase ini berupa penawaran produk yang beragam yang sudah disesuaikan terhadap kebutuhan pelanggan, kegiatan menawarkan produk berdasarkan pengalaman pelanggan, dan memberikan pelayanan untuk mendapatkan kepuasan.Enhancement, fase ini merupakan kegiatan yang dilakukan untuk meningkatkan penjualan produk dan meningkatkan penjualan terhadap setiap pelanggan.Retention, fase ini merupakan kegiatan yang membangun pengetahuan terhadap pelanggan dan memberikan penawaran produk kepada pelanggan sesuai dengan pelanggan.

Proses Customer Relationship Management (CRM) merupakan proses pengumpulan data mengenai pelanggan kemudian menganalisisnya (Utami, 2010). Penerapan CRM dapat memberikan pelayanan kepada pelanggan secara efektif dan efisien.

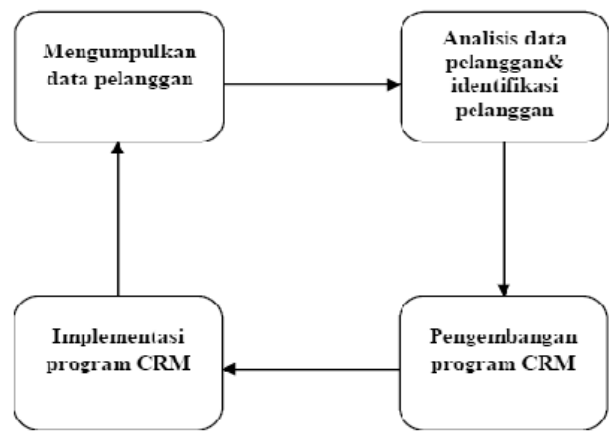

Gambar 1. CRM menurut Utami (2010)

Pada Gambar 1, terdapat proses CRM menurut Utami (2010). Proses tersebut dimulai dengan mengumpulkan data pelanggan, kemudian data tersebut dianalisis dan identifikasi kebutuhan, setelah mendapatkan analisis data tersebut, dilanjutkan dengan pengembangan program CRM, dan yang terakhir adalah menerapkan program CRM tersebut. 


\subsection{Pelanggan}

Menurut Greenberg, pelanggan merupakan seseorang individu atau kelompok yang membeli suatu produk berupa fisik maupun jasa dengan memikirkan faktor keseimbangan, harga, manfaat, kualitas dan jumlah berdasarkan keinginan mereka sendiri. Sedangkan menurut Nasution, pelanggan adalah orang yang membeli sebuah produk yang diinginkan baik berupa barang ataupun jasa.

Dari beberapa definisi pelanggan diatas, dapat disimpulkan bahwa pelanggan adalah seseorang pelaku baik individu ataupun kelompok yang membeli suatu produk baik itu barang dan jasa secara terus menerus di tempat yang sama. Terdapat beberapa jenis - jenis pelanggan yang dapat dipelajari, antara lain Pelanggan Internal, jenis pelanggan ini merupakan pelanggan yang berlokasi didalam suatu perusahaan dan pada umumnya memiliki pengaruh terhadap kinerja perusahaan.Pelanggan antara, jenis pelanggan ini berperan sebagai perantara antara produsen dan konsumen akhir.Pelanggan eksternal, jenis ini merupakan kebalikan dari pelanggan internal, yaitu pelanggan yang biasanya berupa konsumen akhir dari produk atau jasa.

\subsection{Loyalitas Pelanggan}

Menurut Kamus Besar Bahasa Indonesia (KBBI), loyalitas atau sering disebut loyal adalah suatu kepatuhan atau kesetiaan. Sedangkan Loyalitas Pelanggan merupakan pelanggan yang tidak hanya membeli ulang suatu barang dan jasa, tetapi juga mempunyai komitmen dan sikap yang positif terhadap perusahaan jasa, misalnya dengan merekomendasikan orang lain untuk membeli. (Gremler dan Brown, 2008). Sedangkan menurut Griffin (2003), loyalitas pelanggan adalah sebuah perasaan senang dan puas terhadap pelayanan yang didapat dan tidak akan mencoba produk yang lain.

Dari beberapa pengertian loyalitas pelanggan menurut para ahli diatas, dapat disimpulkan bahwa loyalitas pelanggan adalah sebuah perasaan senang dan puas seseorang terhadap pelayanan yang didapat sehingga seseorang tersebut akan sering membeli produk dan jasa tersebut untuk mendapatkan pelayanan secara terus menerus.

\subsection{Marketplace}

Berdasarkan definisi Marketplace merupakan sebuah wadah jual beli yang melakukan kegiatan menjual suatu barang ataupun jasa kepada para pembeli. Biasanya Marketplace berbentuk pasar Elektronik atau Online. Di Indonesia, PT Tokopedia Indonesia adalah salah satu contoh model bisnis marketplace. Dengan menggunakan website tokopedia.com. Namun, konsep marketplace berbeda dengan konsep Toko Online. Toko Online dapat dilustrasikan sebagai sebuah toko retail yang menjual produk nya secara virtual. Salah satu contoh dari toko online adalah Bhineka.com. Toko Online tersebut merupakan situs e-commerce yang menjadi pelopor toko online di Indonesia, bahkan, bhineka.com menjadi salah satu situs toko online terbesar di Indonesia sejak dibuat pada tahun 1997. Sedangkan marketplace dapat diilustrasikan sebagai sebuah pasar tradisional yang mempunyai banyak orang berkumpul didalam satu tempat untuk melakukan kegiatan - kegiatan jual beli secara online. Biasanya pihak marketplace berperan sebagai perantara penjual dan pembeli dalam bentuk website yang bertujuan untuk mewadahi pertemuan dan melakukan transaksi secara legal antara pihak penjual dengan pembeli.

\section{METODE PENELITIAN}

Metode penelitian yang digunakan dalam melakukan penelitian ini adalah metode deskriptif. Metode ini dipakai karena dianggap sebagai metode yang cocok dalam mengumpulkan data yang dibutuhkan. Biasanya langkah - langkah dalam metode dekriptif, yakni mengidentifikasi adanya permasalahan yang signifikan untuk dipecahkan melalui metode deskriptif, membatasi dan merumuskan permasalahan secara jelas, menentukan tujuan dan manfaat penelitian, melakukan studi pustaka yang berkaitan dengan permasalahan. Menentukan kerangka berfikir dan pertanyaan penelitian atau hipotesis, mendesain metode 
penelitian yang hendak digunakan termasuk menentukan populasi, sampel, teknik sampling, dan menganalisis data, dan yang terakhir adalah membuat laporan penelitian.

\subsection{Pengumpulan Data}

Proses pengumpulan data yang diperlukan untuk mendukung penelitian ini dilakukan dengan memberikan kuisioner kepada orang - orang yang sering melakukan transaksi atau orang yang mengetahui website tokopedia.com. Pada penelitian ini responden dari kuisioner tersebut adalah pelaku bisnis dan pembeli tokopedia yang berada di kota Bandung, Jawa Barat.

Pengumpulan data berupa kuisioner dan survey terhadap pelayanan PT Tokopedia Indonesia melalui website jual beli online nya. Tujuan dari pengumpulan data ini adalah untuk melihat data - data tingkat kepuasan dan loyalitas seseorang terhadap website tokopedia.com.

\subsection{Analisis Data}

Langkah selajutnya adalah menganilisis data yang sudah didapat dari hasil pengumpulan data yang sudah dilakukan sebelumnya. Pada pengumpulan data terhadap pelaku bisnis online dan pembeli online tokopedia.com didapatkan data berupa grafik sebagai berikut:

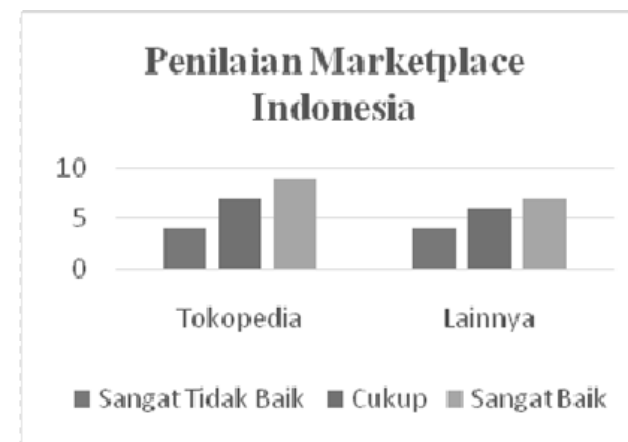

Gambar 2. Grafik Penilaian Pelayanan Marketplace di Indonesia

Pada Gambar 2, terdapat grafik yang menunjukkan data yang didapat dalam mengukur tingkat pelayanan marketplace yang ada di Indonesia, salah satunya adalah Tokopedia. Disana terdapat data yang menunjukkan bahwa tokopedia memiliki nilai yang lebih dari marketplace lainnya yang ada di Indonesia.

Selain itu, data yang didapat dari hasil pengumpulan data yang telah dilakukan adalah mengukur seberapa sering seorang melakukan aktiifitas didalam website tokopedia.com. Data tersebut dapat dilihat pada Gambar 3.

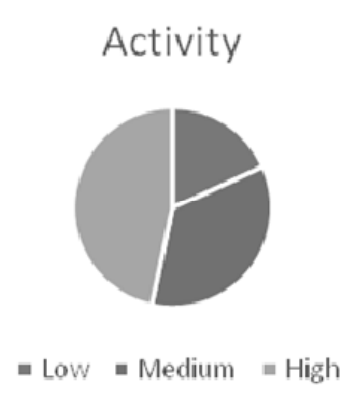

Gambar 2. Tingkat Aktifitas Pengguna.

Pada Gambar 2, dapat dilihat aktifitas pengguna didalam website tokopedia.com baik melakukan aktifitas jual beli maupun hanya melihat katalog penjualan saja. Pada Gambar 2 tersebut dapat dilihat intensitas pengguna cukup tinggi pada website tokopedia.com.

Pada kuisioner yang diberikan, terdapat juga data tingkat kepercayaan pengguna terhadap keamanan aktifitas jual beli online. Kepercayaan pelanggan menjadi prioritas bagi PT 
Tokopedia Indonesia dalam menjaga hubungan pelanggan terhadap website jual beli online nya.

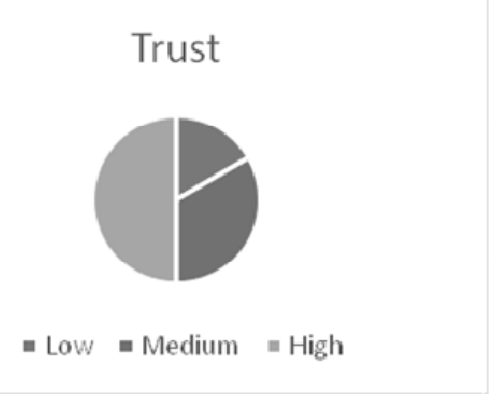

Gambar 3. Tingkat kepercayaan pengguna

Pada Gambar 3 merupakan grafik yang menunjukkan tingkat kepercayaan pengguna terhadap pelayanan yang diberikan didalam website, pada grafik tersebut menunjukkan tingkat kepercayaan yang cukup tinggi. Pada data tersebut dapat dilihat tingkat loyalitas pengguna terhadap tokopedia yang cukup tinggi dari marketplace lainnya di Indonesia. Kepercayaan pengguna sangat penting bagi pelaku bisnis secara online karena dengan kepercayaan pengguna terhadap produk nya akan menentukan jalannya marketplace.

\subsection{Dampak Penerapan CRM}

Dampak penerapan Customer Relationship Management (CRM) pada Tokopedia memiliki beberapa dampak, antara lain membantu mengetahui keinginan pelanggan, dengan adanya customer relationship management, pelaku bisnis dapat mengidentifikasi dan menganalisis keinginan dan kebutuhan pelanggan dengan berhubungan langsung melalui media elektronik, membantu Tokopedia dalam mengetahui segmen pelanggan, penerapan CRM sangat membantu pelaku bisnis dalam mengetahui segmen pelanggan nya, biasanya dikategorikan kedalam segmen pelanggan anak - anak, remaja dan dewasa, membantu Tokopedia dalam berinteraksi langsung dengan pelanggannya, dengan adanya website tokopedia.com, PT Tokopedia dapat secara langsung berinteraksi dengan semua pelanggan nya dengan cepat.

\section{KESIMPULAN}

Kesimpulan yang dapat diambil dari hasil penelitian yang dilakukan adalah sebagai berikut

- Dengan diterapkannya Customer Relationship Management pada Tokopedia mempengaruhi tingkat kepuasan dan loyalitas pelanggan terhadap perusahaan, hal ini dapat dilihat dari data - data yang didapatkan. Data tersebut menunjukkan bahwa tingkat kepuasan pelanggan cukup tinggi, dengan tingkat kepuasan seperti itu akan berbanding lurus dengan tingkat loyalitas pelanggan.

- Penerapan CRM pada perusahaan sangat berperan penting dalam membangun hubungan yang baik dengan pelanggan.

- CRM merupakan strategi yang dapat diterapkan pada perusahaan yang memiliki segmen pelanggan yang beragam

- Dengan adanya CRM dapat diketahui keinginan dan kebutuhan pelanggan.

\section{DAFTAR PUSTAKA}

Carissa, A. O. (2014). Penerapan Customer Relationship Management (Crm) Sebagai Upaya Untuk Meningkatkan Loyalitas Pelanggan. Jurnal Administrasi Bisnis (JAB) Vol. 15 No. 1 Oktober 2014. 
Iriandini, A. P. (2015). Pengaruh Customer Relationship Management (Crm) Terhadap Kepuasan Pelanggan Dan Loyalitas Pelanggan. Jurnal Administrasi Bisnis (JAB)|Vol. 23 No. 2 Juni 2015.

Kalalo, R. E. (2014). Customer Relationship Management Dan Kualitas Pelayanan Pengaruhnya Terhadap Loyalitas Konsumen Pt. Matahari Dept. Store, Manado. ISSN 2303-1174.

Long, C. S. (2013). Impact of CRM Factors on Customer Satisfaction and Loyalty. Asian Social Science; Vol. 9, No. 10; 2013.

Maulana, S. M. (2015). Implementasi E-Commerce Sebagai Media Penjualan Online. Jurnal Administrasi Bisnis (JAB) Vol. 29 No. 1 Desember 2015. 